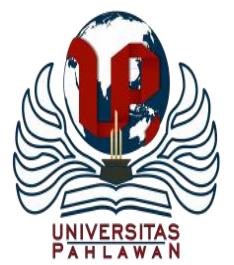

Edukatif : Jurnal Ilmu Pendidikan Volume 3 Nomor 4 Tahun 2021 Halm 1395 - 1408

EDUKATIF: JURNAL ILMU PENDIDIKAN

Research \& Learning in Education

https://edukatif.org/index.php/edukatif/index

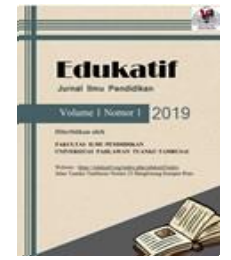

\title{
Analisis Jawaban Mahasiswa dalam Menyelesaikan Soal Pembuktian Geometri Berdasarkan Teori Newman
}

\author{
Syifa Afidah Nurul Arifin ${ }^{凶}$ \\ Program Studi Pendidikan MIPA, Fakultas Pascasarjana, Universitas Indraprasta PGRI, Jakarta \\ E-mail : syifaafidahna@gmail.com
}

\begin{abstract}
Abstrak
Proses identifikasi kesalahan pada jawaban mahasiswa dalam menyelesaikan soal pembuktian geometri perlu dilakukan agar tidak menyebabkan kesalahan berulang pada mata kuliah geometri lanjutan. Penelitian ini bermaksud menelaah kesalahan berdasarkan Teori Newman pada jawaban mahasiswa dalam mengerjakan soal pembuktian geometri agar dapat mengetahui karakteristik, penyebab serta solusi meminimalisir kesalahan. Metode penelitian yang digunakan adalah penelitian kualitatif deskriptif dengan pendekatan fenomenografi. Sebanyak 15 mahasiswa menjadi subjek penelitian serta instrumen yang digunakan adalah dokumentasi dan pedoman wawancara. Subjek penelitian ini sebanyak 15 mahasiswa serta instrumen yang digunakan yaitu pedoman wawancara dan dokumentasi. Adapun jenis kesalahan berdasarkan Teori Newman yang digunakan dalam penelitian ini adalah: (1) kesalahan membaca representasi simbol matematis; (2) kesalahan memahami masalah pembuktian; (3) kesalahan transformasi masalah pembuktian; (4) kesalahan keterampilan proses pembuktian; dan (5) kesalahan penulisan jawaban. Penelitian ini memperoleh hasil bahwa terdapat beberapa karakteristik kesalahan salah satunya gagal menentukan prosedur pembuktian yang sistematis. Penyebab mahasiswa melakukan kesalahan tersebut dikarenakan tidak memahami hubungan antar konsep terkait informasi yang diketahui. Sering berlatih soal-soal non-rutin dapat dijadikan solusi meminimalisir kesalahan pembuktian geometri.
\end{abstract}

Kata Kunci: Analisis Jawaban, Jenis Kesalahan, Pembuktian Geometri, Teori Newman.

\begin{abstract}
The process of identifying errors in students' answers in solving geometry proof questions needs to be done so as not to cause repeated errors in advanced geometry courses. This study intends to study errors based on Newman's theory on students' answers in working on geometry evidentiary questions to know the characteristics, causes, and solutions to minimize errors. The research method used is descriptive qualitative research with a phenomenographic approach. A total of 15 students were the subject of research and the instruments used were documentation and interview guidelines. The subjects of this study were 15 students and the instruments used were interview guidelines and documentation. The types of errors based on Newman's Theory used in this study are (1) reading errors; (2) comprehension errors; (3) transformation errors; (4) process skills errors; and (5) encoding errors. The study obtained the results that there are several characteristics of errors, one of which failed to determine systematic evidentiary procedures. The reason students make these mistakes is that they do not understand the relationship between concepts related to known information. Often practicing non-routine questions can be used as a solution to minimize errors of geometry proof.
\end{abstract}

Keywords: Answer Analysis, Error Types, Proof of Geometry, Newman's Theory.

Copyright (c) 2021 Syifa Afidah Nurul Arifin

$\triangle$ Corresponding author:

Email : syifaafidahna@gmail.com

DOI : https://doi.org/10.31004/edukatif.v3i4.564

ISSN 2656-8063 (Media Cetak)

ISSN 2656-8071 (Media Online)

Edukatif : Jurnal Ilmu Pendidikan Vol 3 No 4 Tahun 2021 p-ISSN 2656-8063 e-ISSN 2656-8071 
1396 Analisis Jawaban Mahasiswa dalam Menyelesaikan Soal Pembuktian Geometri Berdasarkan Teori Newman - Syifa Afidah Nurul Arifin

DOI: https://doi.org/10.31004/edukatif.v3i4.564

\section{PENDAHULUAN}

Ilmu matematika mempunyai salah satu ciri khas yang membuat unik dan beda antara disiplin ilmu lain diantaranya dalam pembuktian. Pembuktian adalah suatu kebenaran dari pernyataan yang dijelaskan oleh rangkaian argumen logis (Syafri, 2019: 53). Rangkaian argumen tersebut bersumber dari asumsi pernyataan itu sendiri, ataupun dari definisi, postulat-postulat maupun aksioma. Pembuktian merupakan kesahihan suatu pernyataan yang ditunjukkan melalui proses bernalar, sedangkan bukti merupakan hasil dari pembuktian (Maryono et al., 2018: 73). Dalam proses menyelesaikan dan mengonstruksi suatu pembuktian matematika tersirat makna yang baik untuk mengembangkan kemampuan berpikir abstrak mahasiswa (Lestari, 2018: 83). Pembuktian matematis sering digunakan dalam persoalan matematika yang sifatnya abstrak, satu diantaranya adalah geometri.

Geometri merupakan penemuan sifat-sifat baru dengan landasan fakta yang dapat diterima dan dikenal dengan menggunakan proses penalaran deduktif secara sistem matematis (Masfingatin et al., 2018: 43). Pembuktian geometri merupakan serangkaian argumen logis untuk menemukan jawaban mengapa serta bagaimana hingga mendapatkan pernyataan tersebut. Geometri sebagai sistem deduktif, dimana kebenaran suatu pernyataan teorema, aksioma, maupun definisi harus dibuktikan secara sistematis dan logis. Teorema merupakan suatu pernyataan dalam deduksi yang kebenarannya harus dibuktikan. Mayoritas pernyataan dalam teorema lazimnya berupa pernyataan implikasi maupun biimplikasi. Geometri bersifat abstrak sehingga dalam pemahaman materinya diperlukan visualisasi yang relatif tinggi (Hanafi, 2018: 274).

Kemampuan pembuktian matematis adalah kemampuan dalam memahami simbol matematika atau premis serta membentuk bukti kebenaran dari suatu pernyataan secara sistematis sesuai dengan prinsip, teorema, dan definisi yang ada sebelumnya. Hal tersebut dapat dikatakan penting sebab teori dan praktek bermatematika yang disertai pembuktian merupakan cerminan dari pembelajaran matematika. Dua konsep tersebut saling berkaitan karena dalam matematika perlu adanya suatu kebenaran yang tidak dapat diwakilkan dengan hanya menentukan benar atau salah (Hermanto et al., 2016: 12). Para mahasiswa hendaknya mengembangkan kebiasaan memberi penjelasan atau argumentasi sebagai bagian lengkap dari setiap penyelesaian pembuktian, membuat dan memeriksa asumsi-asumsi matematis, menentukan dan menggunakan beragam metode pembuktian dan jenis pemahaman. Serta mahasiswa juga hendaknya mengembangkan, mengevaluasi argumen dan bukti matematika (Sutarto, 2018: 904).

Geometri adalah satu diantara mata kuliah yang mengharuskan mahasiswanya mempunyai kemampuan pembuktian matematis. Mata kuliah geometri ini juga merupakan mata kuliah wajib yang diampu oleh mahasiswa Pendidikan Matematika UIN Sunan Gunung Djati Bandung pada semester ganjil tahun pertama. Oleh karena itu, mahasiswa harus memiliki kemampuan pembuktian matematis khususnya pada mata kuliah geometri agar dapat mengonstruksi prinsip-prinsip geometri dengan argumen yang logis. Maksud daripada mahasiswa mempunyai kemampuan memberikan argumen yang logis, belajar untuk bernalar yaitu mahasiswa cakap menggunakan penalaran dalam menerapkan pola dan sifat, dapat melakukan manipulasi, mengonstruksi bukti dan menjelaskan gagasan matematika (Jihad, 2018: 135).

Pola pemikiran matematika yang deduktif aksiomatik serta berlandaskan kebenaran, membuat munculnya permasalahan yang baru (Imswatama \& Muhassanah, 2016: 1-2). Salah satu permasalahan matematika yakni rendahnya hasil belajar mahasiswa saat diberikan permasalahan oleh dosen dikarenakan ketidakmampuan mahasiswa dalam menyelesaikan masalah matematika (Jana, 2018: 9). Terdapat beberapa kesalahan ketika mengerjakan permasalahan matematika khususnya mata kuliah Geometri dalam penyelesaian soal pembuktian diantaranya, mahasiswa kesulitan menuliskan hasil pemikirannya, mahasiswa kesulitan menentukan alasan dan prosedur pembutian dengan menggunakan teorema, lemma dan definisi (Utami, 2016: 86). Adapun permasalahan tersebut perlu menjadi perhatian dosen mata kuliah yang bersangkutan agar tujuan pembelajaran tercapai. Salah satu solusi dalam memecahkan permasalahan mahasiswa perihal kesalahan 
1397 Analisis Jawaban Mahasiswa dalam Menyelesaikan Soal Pembuktian Geometri Berdasarkan Teori Newman - Syifa Afidah Nurul Arifin

DOI: https://doi.org/10.31004/edukatif.v3i4.564

dalam menyelesaikan soal adalah dengan cara menemukan kesalahan yang dikerjakan mahasiswa agar supaya mengetahui letak kesalahan serta memperbaiki hasil belajarnya (Amir, 2015: 134).

Pada pembelajaran di kelas, khususnya saat menyelesaikan pembuktian matematis mata kuliah Geometri mahasiswa sering melakukan kesalahan. Iskandar dan Andriyani menyebutkan bahwa diperoleh beberapa kesalahan, diantaranya yaitu konsistensi jawaban dan kekeliruan sistematis yang terjadi oleh karena tingkat penguasaan materi yang masih kurang pada mahasiswa (Iskandar \& Andriyani, 2016: 964). Kesalahan dalam menyelesaikan permasalahan terjadi salah satunya karena rendahnya tingkat penguasaan materi, akan tetapi ada kesalahan yang bersifat insedental yaitu kurang seksama dalam membaca kehendak soal (Fitriyah, 2016: 19). Dapat disimpulkan dari penelitian tersebut, masalah yang ditemukan adalah mahasiswa memberi respon yang kurang baik dalam menghadapi permasalahan pembuktian geometri.

Suatu konsepsi yang bertentangan dengan pengertian ilmiah yang sudah diterima para pakar bidang tertentu dapat disebut sebagai kesalahan konstruksi konsep atau miskonsepsi (Yustinaningrum \& Lubis, 2019: 40). Miskonsepsi adalah pengertian yang keliru mengenai konsep, kekacauan konsep-konsep yang berbeda, pengelompokkan pemisalan yang keliru, penggunaan konsep yang salah, dan keterkaikatan antara kedudukan konsep-konsep yang tidak sesuai. Miskonsepsi juga sering disebut sebagai konsepsi alternatif. Adanya kesalahan dan miskonsepsi yang terjadi dapat menjadi kesulitan mahasiswa yang akan berdampak pada penyelesaian masalah yang dihadapi.

Kesalahan yang dilakukan mahasiswa hendaknya ada analisis lanjutan, agar memperoleh gambaran yang rinci dan nyata atas kekurangan-kekurangan mahasiswa dalam menyelesaikan permasalahan matematika (Nurussafa'at et al., 2016: 177). Analisis data adalah proses identifikasi suatu kekeliruan yang menyimpang dari sebenarnya. Ketterlin dan Yovanoff menyebutkan bahwa analisis kesalahan ialah suatu prosedur yang dapat dipakai untuk menyelidiki kekeliruan dalam mempelajari konsep matematika yang dilakukan oleh peserta didik (Sulistyorini, 2017: 92). Menurut Riccomini "Objective error analysis involves reviewing student's inependent work to identify spesific patterns and types of erros and help establish precedence of teaching" (Riccomini, 2016: 24). Adapun tujuan analisis kesalahan ialah mengulang kembali hasil pekerjaan mahasiswa untuk mengidentifikasi bentuk dan model kesalahan secara detail serta mendukung dalam memilih prioritas pada pembelajaran.

Fungsi adanya penelitian identifikasi kesalahan menurut Brown dan Skow dalam Sulistyorini adalah membantu dosen untuk: (1) mengidentifikasi tugas yang diselesaikan mahasiswa untuk mengetahui langkah yang mana mahasiswa melakukan kesalahan, (2) mengetahui karakteristik kesalahan yang dilakukan mahasiswa, (3) menentukan penyebab kesalahan yang terjadi hanya sesaat atau miskonsepsi dasar, dan (4) ketepatan dalam menentukan pendekatan pembelajaran yang efisien dan efektif agar dapat menjadikan solusi dari keslahpahaman mahasiswa (Sulistyorini, 2017: 95). Menurut Csáky, Szabová \& Naštická, pengkategorian dalam menyelesaikan suatu permasalahan dalam soal ada 5 yaitu kesalahan membaca masalah, kesalahan menafsirkan masalah, kesalahan mentransformasi, kesalahan kemampuan berproses, dan kesalahan penyusunan hasil akhir jawaban (Csáky et al., 2015: 69). Hal tersebut sesuai dengan mahasiswa saat menyelesaikan masalah pembuktian geometri, yang mana soal pembuktian disajikan dalam bentuk uraian dan penyelesaianya harus terstruktur. Oktiviana juga menyebutkan bahwa Teori Analisis Newman ini dibuat sebagai prosedur diagnostik elementer dalam memecahkan soal uraian matematika. Oleh karena itu, pada penelitian kali ini peneliti menggunakan Teori Newman sebagai acuan dalam mengidentifikasi kesalahan mahasiswa dalam pembuktian.

Anne Newman adalah orang yang pertama kali memperkenalkan metode ini di Austria pada tahun 1977. Teori Newman ini, menyebutkan bahwa ada lima usaha spesifik sebagai suatu hal yang krusial untuk memudahkan dalam mendapatkan letak kesalahan serta penyebab kesalahan yang dilakukan (Kania \& Arifin, 2019: 3). Berikut kategori kesalahan sesuai dengan Teori Newman yang dipergunakan dalam penelitian ini yaitu: (1) kesalahan membaca representasi simbol matematis (reading errors); (2) kesalahan memahami 
masalah pembuktian (comprehension errors); (3) kesalahan transformasi masalah pembuktian (transformation errors); (4) kesalahan keterampilan proses pembuktian (process skills errors); dan (5) kesalahan penulisan jawaban (encoding errors).

Adapun penelitian yang dilakukan oleh Nok I. Yazidah pada tahun 2017 dengan judul penelitian "Analisis Kesalahan Menyelesaikan Soal Pembuktian Geometri Euclid Ditinjau Dari Gender pada Mahasiswa IKIP Budi Utomo Malang”. Penelitian tersebut memperoleh hasil bahwa tidak ada pengaruh gender dalam menyelesaikan soal pembuktian geometri Euclid. Kesalahan yang banyak terjadi dalam penelitian tersebut adalah kesalahan konseptual (Yazidah, 2017: 71). Dari penelitian tersebut, peneliti bermaksud untuk lebih memperdalam hasil temuan mengenai analisis kesalahan dalam menyelesaikan pembuktian geometri. Perbedaan penelitian ini dengan penelitian terdahulu yaitu penelitian ini membahas lebih detail mengenai bagaimana karakteristik, penyebab, dan solusi untuk kesalahan dalam membuktikan yang ditinjau berdasarkan Teori Newman. Penelitian ini menganalisis jawaban mahasiswa pada tiga tes pembuktian geometri. Pada setiap tes selesai dilaksanakan, peneliti menganalisis lembar jawaban mahasiswa tersebut dan langsung mengonfirmasi jawaban melalui wawancara. Saat wawancara juga, peneliti menginformasikan pada subjek penelitian dimana letak kesalahan dan memberi solusi. Hal tersebut yang menjadikan penelitian ini berbeda dengan penelitian sebelumnya.

Adapun kondisi ideal yang seharusnya adalah mahasiswa dapat melakukan pembuktian geometri secara sistematis. Namun, berdasarkan penelitian sebelumnya dan melihat kondisi di lapangan ternyata belum sepenuhnya mahasiswa dapat melakukan pembuktian tersebut. Oleh karena itu terdapat kesenjangan antara keadaan sekarang dengan keadaan ideal. Analisis kesenjangan yang dimaksud merupakan kesenjangan antara harapan mahasiswa dapat menyelesaikan soal pembuktian geometri yang sistematis dengan hasil pembuktian yang diperoleh. Sehingga analisis ini dapat menjadi solusi untuk menyelesaikan masalah yang telah dijelaskan. Serta dengan adanya penelitian ini juga diharapkan akan mengurangi kesenjangan tersebut.

Berdasarkan permasalahan yang telah dipaparkan, hubungan antara pentingnya analisis kesalahan dilakukan untuk meminimalisir kesalahan terjadi berulang dengan lima indikator analisis kesalahan Teori Newman dalam masalah pembuktian geometri merupakan hal penting. Dimana jika tidak dilakukan analisis kesalahan maka kemungkinan akan terjadi kesalahan yang sama secara berulang. Sehingga penelitian ini penting dilakukan sebagai upaya membentuk kemampuan pembuktian matematis mahasiswa yang akan menjadi pendidik di masa depan. Sebagaimana geometri ini merupakan mata kuliah yang menjadi dasar dan prasyarat mata kuliah geometri lanjutan. Serta diperkuat oleh saran peneliti sebelumnya yang mengemukakan perlu adanya analisis deteksi kesalahan untuk memperdalam kesulitan mahasiswa dalam menyelesaikan masalah menggunakan Teori Newman (Suwanti \& Fayeldi, 2018: 83). Analisis kesalahan yang dilakukan pada penelitian ini diharapkan dapat dijadikan dasar oleh dosen atau pengajar dalam memberikan bantuan secara tepat untuk mahasiswa dalam menghindari dan meminimalisir kesalahan yang banyak dilakukan dan dapat dijadikan sebagai bahan refleksi untuk menentukan hal-hal apa saja yang sebaiknya difokuskan pada saat pembelajaran. Dari uraian permasalahan tersebut, peneliti bertujuan untuk mengidentifikasi jawaban mahasiswa guna mengetahui karakteristik, penyebab, serta solusi dalam mengerjakan soal pembuktian pada mata kuliah geometri menurut Teori Newman.

\section{METODE PENELITIAN}

Penelitian ini menggunakan metode kualitatif deskriptif menggunakan strategi fenomenografi, karena peneliti bermaksud untuk mengkaji mengenai karakteristik, penyebab serta solusi untuk meminimalisir kesalahan mahasiswa dalam mengerjakan soal pembuktian pada mata kuliah geometri. Lokasi penelitian ini dilakukan di Prodi Pendidikan Matematika Fakultas Tarbiyah dan Keguruan Universitas Islam Negeri Sunan Gunung Djati Bandung. Teknik pengumpulan data menggunakan dokumentasi dan wawancara. Dokumentasi yang digunakan adalah lembar jawaban mahasiswa soal pembuktian pada tes UTS, Kuis, dan UAS. Subjek 
1399 Analisis Jawaban Mahasiswa dalam Menyelesaikan Soal Pembuktian Geometri Berdasarkan Teori Newman - Syifa Afidah Nurul Arifin

DOI: https://doi.org/10.31004/edukatif.v3i4.564

penelitian ini sebanyak 15 orang mahasiswa yang dikategorikan sebagai kelas tinggi 5 orang subjek, kelas sedang 5 orang subjek, dan kelas rendah 5 orang subjek. Pemilihan subjek penelitian dengan pertimbangan bahwa mahasiswa dari kategori tinggi, sedang, rendah melakukan lima kesalahan sesuai indikator kesalahan Teori Newman saat menyelesaikan soal pembuktian geometri. Pengelompokkan mahasiswa kategori kemampuan tinggi, sedang dan rendah.

\begin{tabular}{ccc}
\multicolumn{3}{c}{ Tabel 1 Penentu Kategori Kelas Tinggi, Sedang dan Rendah } \\
\hline Ketentuan $(\mathbf{X})$ & $\begin{array}{c}\text { Kategori } \\
\text { Kelas }\end{array}$ & Jumlah Mahasiswa \\
& Tinggi & 31 \\
$X>59$ & Sedang & 63 \\
$59 \leq X \leq 29$ & Rendah & 31 \\
$X<29$ &
\end{tabular}

Analisis data kualitatif yang digunakan adalah analisis data Miles dan Huberman yang dibagi menjadi tiga, yaitu: 1) Reduksi data, peneliti menyiapkan dan mengoreksi soal pembuktian. Kemudian, memilih subjek penelitian sesuai dengan kriteria jenis kesalahan Teori Newman pada setiap kategori kelas tinggi, sedang, dan rendah. 2) Penyajian data, peneliti menyajikan hasil pekerjaan mahasiswa yang dipilih sebagai subjek penelitian dan hasil wawancara. 3) Penarikan kesimpulan, peneliti membandingkan analisis lembar jawaban hasil tes dan wawancara mahasiswa yang menjadi subjek penelitian menggunakan teknik triangulasi data.

\section{HASIL DAN PEMBAHASAN PENELITIAN}

Tahapan pada riset ini menggunakan metode fenomenografi yaitu tahap rencana, pengumpulan, analisis, dan interpretasi data. Pada tahap perencanaan penelitian ini yang dilakukan peneliti adalah menyiapkan soal UTS dan UAS yang telah dibuat oleh dosen mata kuliah geometri. Begitu pula soal kuis yang diadaptasi dari buku Geometry for Elementary School. Berdasarkan hasil UTS yang dilakukan dengan mengecek jawaban soal pembuktian yang telah dilakukan, diperoleh 15 subjek penelitian yang terdiri atas 5 subjek penelitian kategori tinggi, 5 subjek penelitian kategori sedang, dan 5 subjek penelitian kategori rendah. Semua subjek penelitian ini melakukan kesalahan sesuai dengan jenis kesalahan Teori Newman, berikut Tabel 2 yang menunjukkan daftar kode subjek penelitian.

Tabel 2 Daftar Kode Subjek Penelitian

\begin{tabular}{ccc}
\hline No & Kode Subjek & Kategori \\
\hline 1. & T1, T2, T3, T4, T5 & Subjek penelitian kelas tinggi \\
2. & S1, S2, S3, S4, S5 & Subjek penelitian kelas sedang \\
3. & R1, R2, R3, R4, R5 & Subjek penelitian kelas rendah \\
\hline
\end{tabular}

Pada tahap pengumpulan data yaitu data yang dikumpulkan berasal dari lembar jawaban hasil tes yang dikerjakan oleh subjek penelitian yang selanjutnya dilakukan wawancara untuk mendapatkan akurasi data. Adapun lembar jawaban hasil tes geometri yang dianalisis hanya butir soal pembuktian. Data pada penelitian ini tersedia dalam bentuk deskripsi dan tabel dari hasil analisis tes serta wawancara. Analisis tes ini meliputi soal UTS nomor 2, 3, dan 5, soal kuis, soal UAS nomor 1 dan 3. Hasil analisis dokumentasi jawaban dan wawancara akan diuraikan berdasarkan kesalahan dalam menyelesaikan soal pembuktian geometri menurut Teori Newman. Berikut pada Tabel 3 ini merupakan kode yang digunakan pada gambar untuk menunjukkan jenis kesalahan Teori Newman:

Tabel 3

Daftar Kode Jenis Kesalahan Teori Newman

\begin{tabular}{clc}
\hline No & \multicolumn{1}{c}{ Jenis Kesalahan Teori Newman } & Kode \\
\hline 1. & Kesalahan membaca representasi simbol matematis (reading errors) & RE \\
2. & Kesalahan memahami masalah pembuktian (comprehension errors) & CE \\
3. & Kesalahan mentransformasikan pembuktian (transformation errors) & TE
\end{tabular}


1400 Analisis Jawaban Mahasiswa dalam Menyelesaikan Soal Pembuktian Geometri Berdasarkan Teori Newman - Syifa Afidah Nurul Arifin

DOI: https://doi.org/10.31004/edukatif.v3i4.564

\begin{tabular}{clc}
\hline No & \multicolumn{1}{c}{ Jenis Kesalahan Teori Newman } & Kode \\
\hline 4. & Kesalahan keterampilan proses pembuktian (process skills errors) & PSE \\
5. & Kesalahan penulisan jawaban (encoding errors) & ECE \\
\hline
\end{tabular}

Berikut ini pada Gambar 1 merupakan salah satu pemaparan analisis data hasil tes dan hasil wawancara dalam bentuk gambar dan tabel dari subjek penelitian.

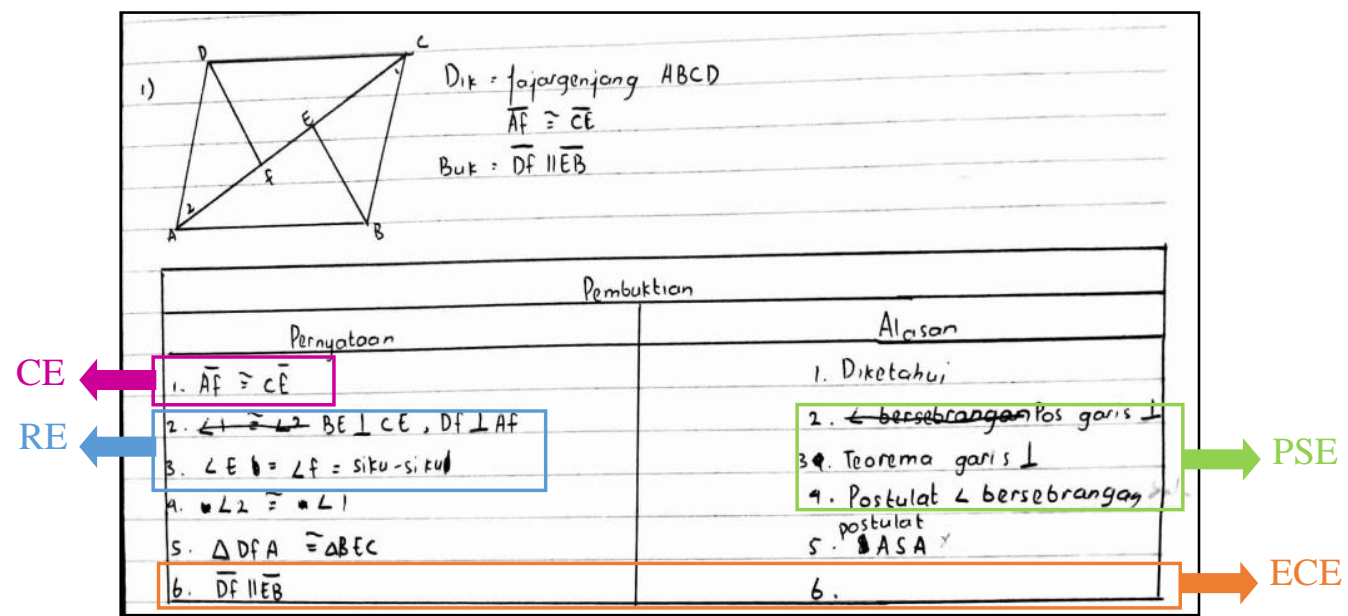

Gambar 1. Jawaban Soal UAS Nomor 1 pada T1

Pada Gambar 1 terlihat bahwa subjek penelitian T1 melakukan jenis kesalahan berdasarkan Teori Newman. Adapun hasil wawancara yang dilaksanakan oleh peneliti terhadap subjek T1 mengenai lembar jawaban UAS nomor 1 ialah sebagai berikut.

$P \quad:$ "Apakah penulisan simbol yang anda gunakan dalam penyelesaian soal tersebut sudah sesuai?"

$T 1$ : "Ini kurang ruas garis $\underline{B E, C E, D F, A F "}$

$P \quad$ : "Apa yang diketahui pada soal tersebut?"

$T 1$ : “Jajargenjang $A B C D$ dan $\overline{A F} \cong \overline{C E}$ "

$P \quad$ : "Dari pernyataan tersebut, apa yang akan Anda buktikan?"

$T 1$ : “ $\overline{D F} \| \overline{E B}$ "

$P \quad$ : "Apakah yang diketahui dan akan dibuktikan sudah dituliskan dalam jawaban Anda?"

$T 1$ : "Sudah tapi disini ada yang ga ditulis alasannya."

$P \quad:$ "Kalau ada pernyataan seperti itu harusnya apa?"

$T 1$ : “Kesejajaran garis, postulat, teorema, masih bingung antara postulat sama teorema"

$P \quad$ : "Coba sesuaikan kembali dengan jawaban Anda."

$T 1$ : "Iya, emang harus ditulis semua (yang diketahui)?"

$P \quad:$ "Iya"

T1 : "Oalah gitu"

$P$ : "Bagaimana Anda mengerjakan soal tersebut? Coba jelaskan setiap langkah dan alasannya"

$T 1$ : "Tulis yang diketahui, kemudian $\overline{B E} \perp \overline{C E}, \overline{D F} \perp \overline{A F}$ jadinya tegak lurus, dari pernyataan tersebut mengakibatkan siku-siku sehingga $\angle E=\angle F$, seharusnya setelah pernyataan $\angle E=\angle F$ ditulis ukuran sudutnya tapi tidak jadi dituliskan karena akan menambah banyak pernyataan. Kemudian ini $(\angle 2 \cong \angle 1)$ bersebrangan, kemudian karena sudah dilihat ini sama $(\angle E=\angle F)$, , ini sama $(\overline{A F} \cong \overline{C E})$, ini sama $(\angle 2 \cong \angle 1)$, jadi sudut sisi sudut. Selanjutnya karena sudah banyak yang kongruen, jadi ini $(\overline{D F} \| \overline{E B})$ ini tuh postulat atau teorema, jadi sejajar dengan alasan teorema kesejajaran seharusnya."

$P \quad:$ "Apa bedanya postulat garis $\perp$ dengan teorema garis $\perp$ ?"

$T 1$ : "Itu sebenarnya teorema atau bukan, jadi bedakan saja" 
1401 Analisis Jawaban Mahasiswa dalam Menyelesaikan Soal Pembuktian Geometri Berdasarkan Teori Newman - Syifa Afidah Nurul Arifin

DOI: https://doi.org/10.31004/edukatif.v3i4.564

Adapun tahap interpretasi terdapat pada Tabel 4 merupakan data triangulasi sumber. Triangulasi sumber ini didapatkan dari hasil membandingkan hasil tes yang dikerjakan oleh mahasiswa kategori kelas tinggi, sedang dan rendah menurut jenis kesalahan Teori Newman.

Tabel 4 Triangulasi Sumber Penelitian

\begin{tabular}{|c|c|c|c|c|}
\hline No & $\begin{array}{c}\text { Jenis Kesalahan Teori } \\
\text { Newman }\end{array}$ & Kategori Kelas Tinggi & $\begin{array}{l}\text { Kategori Kelas } \\
\text { Sedang }\end{array}$ & $\begin{array}{l}\text { Kategori Kelas } \\
\text { Rendah }\end{array}$ \\
\hline 1. & $\begin{array}{l}\text { Kesalahan representasi } \\
\text { simbol } \quad \text { matematis } \\
\text { (reading errors) }\end{array}$ & $\begin{array}{l}\text { Mahasiswa dapat } \\
\text { mengidentifikasi } \\
\text { pembuktian secara tepat } \\
\text { dan kurang lengkap } \\
\text { menuliskan simbol } \\
\text { geometri yang sesuai } \\
\text { kaidah. }\end{array}$ & $\begin{array}{l}\text { Mahasiswa dapat } \\
\text { mengidentifikasi } \\
\text { pembuktian secara } \\
\text { tepat dan kurang } \\
\text { lengkap menuliskan } \\
\text { simbol geometri yang } \\
\text { sesuai kaidah. }\end{array}$ & $\begin{array}{l}\text { Mahasiswa tidak } \\
\text { dapat } \\
\text { mengidentifikasi } \\
\text { secara tepat dan tidak } \\
\text { menuliskan simbol } \\
\text { geometri yang sesuai } \\
\text { kaidah. }\end{array}$ \\
\hline 2. & $\begin{array}{l}\text { Kesalahan memahami } \\
\text { masalah pembuktian } \\
\text { (comprehension errors) }\end{array}$ & $\begin{array}{l}\text { Mahasiswa dapat } \\
\text { menentukan dan } \\
\text { menuliskan apa yang } \\
\text { diketahui, apa yang akan } \\
\text { dibuktikan serta } \\
\text { kontruksi gambar. }\end{array}$ & $\begin{array}{l}\text { Mahasiswa dapat } \\
\text { menentukan apa yang } \\
\text { diketahui dan apa } \\
\text { yang akan dibuktikan, } \\
\text { namun tidak } \\
\text { menuliskan hipotesis } \\
\text { awal dan konstruksi } \\
\text { gambar. }\end{array}$ & $\begin{array}{l}\text { Mahasiswa dapat } \\
\text { menentukan apa yang } \\
\text { diketahui dan apa } \\
\text { yang akan dibuktikan, } \\
\text { namun tidak } \\
\text { menuliskan hipotesis } \\
\text { awal dan konstruksi } \\
\text { gambar. }\end{array}$ \\
\hline 3. & $\begin{array}{l}\text { Kesalahan } \\
\text { mentransformasikan } \\
\text { pembuktian } \\
\text { (transformation errors) }\end{array}$ & $\begin{array}{l}\text { Mahasiswa dapat } \\
\text { menentukan rencana } \\
\text { pembuktian yang } \\
\text { sistematis, }\end{array}$ & $\begin{array}{l}\text { Mahasiswa kurang } \\
\text { lengkap dalam } \\
\text { menentukan rencana } \\
\text { pembuktian. }\end{array}$ & $\begin{array}{l}\text { Mahasiswa tidak } \\
\text { dapat menentukan } \\
\text { rencana pembuktian } \\
\text { yang sistematis. }\end{array}$ \\
\hline 4. & $\begin{array}{l}\text { Kesalahan keterampilan } \\
\text { proses pembuktian } \\
\text { (process skills errors) }\end{array}$ & $\begin{array}{l}\text { Mahasiswa tidak } \\
\text { berhati-hati dalam } \\
\text { menerapkan rencana } \\
\text { pembuktian yang } \\
\text { dipilih. }\end{array}$ & $\begin{array}{l}\text { Mahasiswa tidak } \\
\text { berhati-hati dalam } \\
\text { menerapkan rencana } \\
\text { pembuktian yang } \\
\text { dipilih. }\end{array}$ & $\begin{array}{l}\text { Mahasiswa tidak } \\
\text { berhati-hati dalam } \\
\text { menerapkan rencana } \\
\text { pembuktian yang } \\
\text { dipilih. }\end{array}$ \\
\hline 5. & $\begin{array}{l}\text { Kesalahan } \\
\text { jawaban } \\
\text { errors) }\end{array}$ & $\begin{array}{l}\text { Mahasiswa dapat } \\
\text { menentukan alasan yang } \\
\text { tepat untuk pernyataan } \\
\text { akhir yang akan } \\
\text { dibuktikan. }\end{array}$ & $\begin{array}{l}\text { Mahasiswa tidak dapat } \\
\text { menentukan alasan } \\
\text { yang tepat untuk } \\
\text { pernyataan akhir yang } \\
\text { akan dibuktikan. }\end{array}$ & $\begin{array}{l}\text { Mahasiswa tidak } \\
\text { dapat menentukan } \\
\text { alasan yang tepat } \\
\text { untuk pernyataan } \\
\text { akhir yang akan } \\
\text { dibuktikan. }\end{array}$ \\
\hline
\end{tabular}

Berdasarkan keseluruhan deskripsi data yang telah dipaparkan semua subjek penelitian kategori kelas tinggi, sedang maupun rendah melakukan kesalahan. Mayoritas subjek penelitian melakukan kesalahan ditinjau dari jenis kesalahan Teori Newman yaitu kesalahan keterampilan proses pembuktian. Hal ini kebanyakan subjek menyebutkan bahwa masih bingung menentukan alasan yang tepat untuk setiap pernyataan. Adapun minoritas subjek penelitian melakukan kesalahan memahami masalah. Secara keseluruhan subjek penelitian menuliskan dengan benar hipotesis awal soal yang meliputi informasi yang ditemukan, apa yang akan dibuktikan dan konstruksi gambar. Tabel 5 dan Gambar 2 merangkum jenis kesalahan yang dilakukan subjek penelitian sesuai Teori Newman. 
1402 Analisis Jawaban Mahasiswa dalam Menyelesaikan Soal Pembuktian Geometri Berdasarkan Teori Newman - Syifa Afidah Nurul Arifin

DOI: https://doi.org/10.31004/edukatif.v3i4.564

Tabel 5

Banyak Subjek yang Melakukan Kesalahan pada Setiap Butir Soal Pembuktian Geometri

\begin{tabular}{|c|c|c|c|c|c|c|c|}
\hline \multirow{2}{*}{ No } & \multirow{2}{*}{$\begin{array}{l}\text { Jenis Kesalahan Teori } \\
\text { Newman }\end{array}$} & \multicolumn{6}{|c|}{$\begin{array}{c}\text { Banyak Subjek yang Melakukan Kesalahan pada Setiap Butir } \\
\text { Soal Pembuktian Geometri }\end{array}$} \\
\hline & & $\begin{array}{l}\text { UTS } \\
\text { No2 }\end{array}$ & $\begin{array}{l}\text { UTS } \\
\text { No3 }\end{array}$ & UTS No5 & Kuis & UAS No1 & $\begin{array}{l}\text { UAS } \\
\text { No3 }\end{array}$ \\
\hline 1. & Reading Errors (RE) & 11 & 10 & 7 & 5 & 2 & 8 \\
\hline 2. & Comprehension Errors (CE) & 1 & 0 & 3 & 1 & 3 & 5 \\
\hline 3. & Transformation Errors (TE) & 11 & 12 & 12 & 14 & 9 & 15 \\
\hline 4. & Process Skills Errors (PSE) & 13 & 14 & 11 & 14 & 13 & 14 \\
\hline \multirow[t]{3}{*}{5} & Encoding Errors (ECE) & 14 & 15 & 13 & 6 & 14 & 2 \\
\hline & & \multicolumn{3}{|c|}{$\begin{array}{l}\text { Persentase Jenis } \\
\text { Kesalahan }\end{array}$} & & & \\
\hline & & $-\mathrm{RE}-\mathrm{CE}$ & $\mathrm{TE}=\mathrm{H}$ & $\mathrm{E}-\mathrm{ECE}$ & & & \\
\hline
\end{tabular}

Hasil yang diperoleh adalah persentasi untuk kesalahan membaca representasi simbol matematis (RE) sebesar 15,81\%, persentase kesalahan memahami masalah (CE) sebesar 4,78\%. Kesalahan transformasi masalah (TE) dengan persentase sebesar 26,84\%, persentase kesalahan keterampilan proses pembuktian (PSE) sebesar 29,04\% dan kesalahan penulisan jawaban (ECE) sebesar 23,53\%. Berdasarkan Gambar 2 secara umum terlihat bahwa persentase kesalahan yang paling besar adalah PSE (Process Skills Errors), kesalahan keterampilan proses salah satunya dalam menentukan alasan yang tepat untuk setiap pernyataan yang dipilih. Sedangkan persentase yang paling sedikit yaitu CE (Comprehension Errors), kesalahan memahami masalah yang mana subjek penelitian ini mayoritas sudah mampu memahami masalah pembuktian dengan baik. Subjek penelitian rata-rata sudah mencatat informasi yang diketahui dan apa yang akan dibuktikan pada soal pembuktian geometri tersebut.

Hal ini berbeda dengan peneliti sebelumnya oleh Pamungkas dan Wicaksono yang menghasilkan jenis kesalahan dalam menyelesaikan soal geometri bidang dengan persentase terbesar ada pada encoding error dan persentase terkecil pada reading error (Pamungkas \& Wicaksono, 2019: 8). Namun, ada juga yang hasil penelitiannya sesuai yaitu penelitian yang dilaksanakan oleh Alhassora. Penelitian beliau memperoleh hasil bahwa "The conclusion showed that most of the students were qualified to carry out the first step of Newman's Error (Read and Recode) however they faced challenges in excuting the second to fifth step of Newman's Model (Comprehension, Transformation, Process Skills and Encoding)" (Alhassora et al., 2017: 413). Hasil riset beliau memperlihatkan bahwa sebagian besar mahasiswa mampu melakukan tahap pertama dan kedua Teori Newman yaitu membaca masalah. Akan tetapi, mereka menghadapi kesulitan dalam melakukan tahap kedua hingga lima Teori Newman yaitu kesalahan dalam memahami, mentransformasi masalah dan keterampilan proses menyelesaikannya. 
1403 Analisis Jawaban Mahasiswa dalam Menyelesaikan Soal Pembuktian Geometri Berdasarkan Teori Newman - Syifa Afidah Nurul Arifin

DOI: https://doi.org/10.31004/edukatif.v3i4.564

Penelitian ini terbatas hanya sampai dengan menemukan karakteristik, penyebab serta memberi solusi pada mahasiswa dalam mengerjakan soal pembuktian geometri saja. Kegunaan hasil riset ini adalah sebagai bahan evaluasi dan upaya untuk meningkatkan kemampuan pembuktian matematis mahasiswa Pendidikan Matematika. Sehingga penelitian ini berdampak bagi bidang pendidikan karena dengan riset ini dapat menyiapkan calon pendidik yang matang dan berkemampuan matematis yang baik untuk meningkatkan mutu pendidikan peserta didik di masa depan.

\section{Karakteristik Kesalahan yang Dilakukan oleh Mahasiswa dalam Menyelesaikan Soal Pembuktian Geometri Berdasarkan Teori Newman}

Berdasarkan hasil identifikasi lembar tes dan wawancara pada subjek penelitian, dapat dikenali berbagai kesalahan yang dilakukan mahasiswa dalam mengerjakan soal pembuktian mata kuliah geometri. Hasil analisis data tersebut diperoleh data karakteristik kesalahan yang dilakukan mahasiswa sesuai dengan kesalahan Teori Newman. Adapun karakteristik kesalahan mahasiswa ialah sebagai berikut:

a. Kesalahan membaca representasi simbol matematis (reading errors)

Kesalahan membaca representasi simbol matematis ini bukan hanya membaca masalah, akan tetapi kemampuan dalam mengidentifikasi soal ataupun dalam mengenali istilah penyimbolan pada soal. Berdasarkan penelitian yang dilakukan Singh bahwa reading errors ini meliputi mahasiswa gagal mengenali simbol atau kata-kata pada soal (Singh et al., 2010: 266). Adapun karakteristik kesalahan yang ditemukan pada subjek penelitian adalah mahasiswa tidak menuliskan simbol geometri yang sesuai kaidah, mahasiswa belum mengenali istilah geometri yang ada, mahasiswa tidak dapat mengidentifikasi masalah pembuktian dan mahasiswa menuliskan informasi berupa pernyataan yang tidak diperlukan dalam menyelesaikan masalah pembuktian.

b. Kesalahan memahami masalah (comprehension errors)

Kesalahan memahami masalah adalah kesalahan yang dikerjakan mahasiswa sesudah membaca representasi simbol, akan tetapi tidak dapat mengetahui permasalahan apa yang harus diselesaikan. Sebagaimana data yang diperoleh dari hasil analisis dokumentasi hasil jawaban para subjek penelitian dan wawancara yang dilakukan adalah mahasiswa tidak mengetahui serta tidak menuliskan secara lengkap apa yang diketahui, apa yang akan dibuktikan serta konstruksi gambar pada soal.

c. Kesalahan transformasi masalah (transformation errors)

Kesalahan transformasi masalah khususnya dalam pembuktian merupakan suatu kesalahan yang dikerjakan mahasiswa dalam memilih dan menentukan rencana pembuktian yang tepat. Adapun karakteristik kesalahan jenis ini yang dilakukan mahasiswa diantaranya kesalahan dalam merencanakan pembuktian, gagal dalam menentukan langkah-langkah pembuktian yang tepat serta kurang lengkap saat mengaplikasikan rencana yang dipilih.

d. Kesalahan keterampilan proses (process skills errors)

Kesalahan keterampilan proses adalah mahasiswa yang melakukan kesalahan dalam proses implementasi konsep pembuktian yang dipilih. Mahasiswa mampu menyelesaiakan soal pembuktian, akan tetapi kurang lengakap dalam mengungkap pernyataan dan kurang tepat dalam menentukan alasan tiap pernyataannya. Adapun karakteristik kesalahan yang ditemukan dari data hasil tes dan wawancara subjek penelitian adalah kesalahan melakukan penerapan prosedur pembuktian yang dipilih, kesalahan dalam menentukan alasan tiap pernyataannya, kesalahan dalam mengklarifikasi suatu kebenaran pernyataan dan alasan, serta tidak berhati-hati dalam menentukan setiap langkah pembuktian. Berbagai karakteristik tersebut diperkuat dengan riset Utami yang menghasilkan bahwa mahasiswa kesulitan dalam menuliskan hasil pemikirannya untuk menentukan alasan dan prosedur pembuktian (Utami, 2016: 86).

e. Kesalahan penulisan jawaban (encoding errors) 
1404 Analisis Jawaban Mahasiswa dalam Menyelesaikan Soal Pembuktian Geometri Berdasarkan Teori Newman - Syifa Afidah Nurul Arifin

DOI: https://doi.org/10.31004/edukatif.v3i4.564

Kesalahan penulisan jawaban akhir adalah kesalahan dalam proses penyelesaian masalah yang menimbulkan mahasiswa tidak menentukan alasan tepat pada akhir pembuktian. Penelitian sebelumnya juga menyebutkan bahwa peserta didik tidak menyimpulkan jawaban akhir dengan benar dalam menyelesaikan soal geometri (Riastuti et al., 2017: 4). Adapun karakteristik kesalahan ini berdasarkan data hasil tes dan wawancara adalah tidak teliti dalam menentukan alasan akhir pembuktian, tidak melakukan pemeriksaan kembali pada lembar jawaban yang dikerjakan dan tidak memeriksa kembali apa yang akan dibuktikan, sehingga salah menentukan hasil akhir.

\section{Penyebab Mahasiswa Melakukan Kesalahan dalam Menyelesaikan Soal Pembuktian Geometri Ditinjau Berdasarkan Teori Newman}

Bersumber dari analisis data hasil tes dan hasil wawancara yang didapatkan dari 15 subjek penelitian, ditemukan bahwa semua subjek penelitian melakukan kesalahan pada soal pembuktian geometri yang diberikan. Berikut ini merupakan penyebab terjadinya kesalahan mahasiswa dalam menyelesaikan masalah pembuktian geometri.

a. Kesalahan membaca representasi simbol matematis (reading errors)

Berdasarkan penelitian terdahulu menyebutkan bahwa penyebab kesalahan membaca masalah terjadi karena kurang teliti (Rindyana \& Chandra, 2013: 1). Adapun penyebab kesalahan membaca repsentasi simbol matematis yang dilakukan subjek penelitian diantaranya adalah: 1) Kurang teliti dalam menuliskan simbol; 2) Belum dapat membedakan penggunaan simbol yang tepat;3) Hanya menuliskan apa yang diingat saja; 4) Tidak sepenuhnya memahami konsep istilah yang ada pada geometri.

b. Kesalahan memahami masalah (comprehension errors)

Berdasarkan penelitian terdahulu menyebutkan bahwa penyebab kesalahan pemahaman terjadi karena peserta didik tidak dapat memahami dan menafsirkan kata-kata kunci dalam soal dan tidak membaca pertanyaan dengan hati-hati sehingga tidak ada yang terbaca informasi (Sumule et al., 2018: 2). Adapun penyebab kesalahan dalam memahami masalah pembuktian yang dilakukan oleh subjek penelitian diantaranya adalah: 1) Tergesa-gesa dalam menyelesaikan soal; 2) Kurang teliti dalam memahami dan menuliskan informasi penting yang terdapat pada soal; 3) Tidak memahami maksud soal; 4) Tidak mengetahui pentingnya penulisan hipotesis awal soal.

c. Kesalahan transformasi masalah (transformation errors)

Berdasarkan penelitian terdahulu menyebutkan bahwa penyebab kesalahan transformasi masalah terjadi karena mahasiswa kurang menguasai konsep geometri dasar (Budiarto \& Artiono, 2019: 10). Hasil temuan penyebab terjadinya kesalahan transformasi masalah pembuktian yang dilakukan oleh subjek penelitian diantaranya adalah: 1) Tidak menguasai materi; 2) Kurang memahami konsep rencana pembuktian yang sistematis; 3) Tidak mengingat konsep pembuktian yang dipilih; 4) Kurang latihan soal pembuktian.

d. Kesalahan keterampilan proses (process skills errors)

Berdasarkan penelitian terdahulu menyebutkan bahwa penyebab kesalahan keterampilan proses terjadi karena belum mampu menggunakan definisi maupun teorema yang dimiliki untuk menyusun hubungan yang logis (Masfingatin et al., 2018: 49). Hal tersebut sesuai dengan salah satu penyebab yang ditemukan dalam penelitian ini yaitu kurang teliti dalam menuliskan alasan yang lengkap. Adapun rincian penyebab terjadinya kesalahan keterampilan proses pembuktian yang dilakukan subjek penelitian diantaranya adalah: 1) Ingin lebih cepat menyelesaikan soal; 2) Tidak mengingat konsep pembuktian yang dipilih; 3) Tidak bisa menentukan alasan untuk tiap pernyataan yang digunakan; 4) Kurang teliti dalam menuliskan alasan yang lengkap; 5) Tergesa-gesa dalam menyelesaikan soal; 6) Kurang percaya diri dengan hasil pembuktian yang dipilih; 7) Keterbatasan waktu penyelesaian soal.

e. Kesalahan penulisan jawaban (encoding errors)

Berdasarkan penelitian terdahulu menyebutkan bahwa penyebab kesalahan penulisan jawaban terjadi karena waktu habis sehingga peserta didik tergesa-gesa dalam menjawab soal (Pamungkas \& Wicaksono, 
1405 Analisis Jawaban Mahasiswa dalam Menyelesaikan Soal Pembuktian Geometri Berdasarkan Teori Newman - Syifa Afidah Nurul Arifin

DOI: https://doi.org/10.31004/edukatif.v3i4.564

2019: 7). Adapun penyebab kesalahan yang terjadi saat penulisan jawaban akhir pembuktian oleh subjek penelitian diantaranya adalah: 1) Waktu menyelesaikan soal telah habis; 2) Tidak yankin dengan jawaban; 3) Tidak memeriksa kembali hasil pekerjaannya; 4) Belum selesai menjawab soal; 5) Tidak konsentrasi dalam menyelesaikan soal; 6) Kurang memahami konsep penulisan alasan akhir pembuktian.

\section{Solusi untuk Meminimalisir Kesalahan Mahasiswa dalam Menyelesaikan Soal Pembuktian Geometri}

Adapun rumusan masalah selanjutnya yaitu solusi untuk meminimalisir kesalahan yang dilakukan subjek penelitian dalam menyelesaikan masalah geometri, diantara solusi yang dapat digunakan adalah:

a. Kesalahan membaca representasi simbol matematis (reading errors)

Solusi yang dapat digunakan untuk menimalisir kesalahan subjek penelitian dalam membaca representasi simbol matematis adalah saat latihan soal perlu diingatkan kembali penggunaan simbol yang sesuai dengan kaidah, dalam menyelesaikan soal matematika pastinya ketelitian sangat diperlukan, mahasiswa dibiasakan untuk berlatih soal-soal pembuktian, mahasiswa dianjurkan untuk diberikan kuis agar mengetahui kelancaran pengerjaannya ketika berlangsungnya pembelajaran. Solusi lain pada penelitian terdahulu adalah pengajar sering memberikan literatur geometri yang menunjukkan adanya perubahan peserta didik dalam kelancaran kosa kata atau simbol geometri (Capraro \& Capraro, 2006: 21).

b. Kesalahan memahami masalah (comprehension errors)

Adapun pemecahan yang dapat digunakan untuk meminimalisir kesalahan dalam memahami masalah pembuktian geometri pada mahasiswa diantaranya adalah memberikan konsep pentingnya penulisan hipotesis awal dalam menyelesaikan permasalahan matematika khususnya geometri. Sesuai dengan penelitian sebelumnya dalam menyelesaikan soal matematika perlu adanya identifikasi soal dengan menuliskan informasi penting yang ada dalam soal tersebut (Rosita \& Abadi, 2019: 1061). Solusi lain yaitu mahasiswa lebih sering memperbanyak latihan soal dengan jenis yang berbeda agar mahasiswa terbiasa dengan jenis-jenis soal yang diberikan.

c. Kesalahan transformasi masalah (transformation errors)

Solusi untuk meminimalisir kesalahan mentransformasikan masalah pembuktian yang dapat diterapkan pada mahasiswa diantaranya adalah sering latihan soal pembuktian dengan cara mahasiswa memahami betul konsep pembuktian yang sistematis itu seperti apa agar mahasiswa dapat melakukan pembuktiam dengan pendekatan yang tepat. Mahasiswa sering mengerjakan latihan soal juga merupakan solusi yang diperkuat pada penelitian sebelumnya (Inayah, 2019: 143). Kemudian pada saat proses pembelajaran berlangsung pastikan mahasiswa dapat memahami materi beserta konsep yang diberikan dengan cara latihan soal pembuktian dan tidak tergesa-gesa dalam menyelesaikannya.

d. Kesalahan keterampilan proses (process skills errors)

Adapun penyelesaian masalah yang dapat digunakan untuk meminimalisir kesalahan keterampilan proses pembuktian yang dilakukan subjek penelitian adalah mahasiswa dipastikan memahami maksud dari tujuan yang diminta pada soal. Begitupun perlu dipastikannya mahasiswa memahami konsep dasar geometri supaya mahasiswa dapat menentukan alasan untuk pernyataan yang dipilihnya dan mahasiswa juga perlu mengatur waktu belajar yang tepat. Solusi tersebut diperkuat dengan penelitian Nurjanatin yang menyebutkan kesalahan dapat diminimalisir apabila mahasiswa memperbaiki pola belajar secara rutin (Nurjanatin et al., 2017: 27). Pada saat proses pembelajaran berlangsung pastikan mahasiswa aktif bertanya mengenai hal yang tidak dipahaminya agar tidak terjadi miskonsepsi dalam menyelesaikan soal.

e. Kesalahan penulisan jawaban (encoding errors)

Solusi untuk meminimalisir kesalahan penulisan jawaban akhir pembuktian yang dilakukan subjek penelitian adalah mahasiswa dipastikan untuk selalu menuliskan kesimpulan atau alasan akhir dalam menyelesaikan masalah pembuktian geometri. Berdasarkan penelitian Safitri salah satu solusinya yaitu dengan membiasakan diri dengan mengerjakan soal secara runtut (Safitri, 2017: 79). Kemudian perlunya pemahaman dalam menentukan alasan yang tepat untuk menjawab pernyataan akhir pembuktian, perlu adanya evaluasi 
1406 Analisis Jawaban Mahasiswa dalam Menyelesaikan Soal Pembuktian Geometri Berdasarkan Teori Newman - Syifa Afidah Nurul Arifin

DOI: https://doi.org/10.31004/edukatif.v3i4.564

dalam pembelajaran supaya mahasiswa dapat mengenali letak kesalahan yang dilakukan saat mengerjakan soal pembuktian, dan mengingatkan kembali kepada mahasiswa untuk memeriksa kembali lembar jawabannya guna memastikan tidak ada jawaban yang terlewat ataupun keliru.

\section{KESIMPULAN}

Berdasarkan hasil dan pembahasan yang telah diuraikan, diperoleh simpulan bahwa kesalahan mahasiswa dalam mengerjakan soal pembuktian geometri yang banyak dilakukan adalah kesalahan mentransformasikan masalah. Adapun rincian kesalahan dan karakteristiknya yaitu kesalahan membaca representasi simbol matematis dengan rata-rata 15,81\%, dengan karakteristik kesalahan yaitu mahasiswa tidak menuliskan simbol geometri yang sesuai kaidah. Kesalahan memahami masalah dengan rata-rata 4,78\%, dengan karakteristik kesalahan yaitu mahasiswa tidak menuliskan secara lengkap informasi yang diperoleh, apa yang akan dibuktikan serta konstruksi gambar pada soal. Kesalahan transformasi masalah dengan rata-rata $26,84 \%$, dengan karakteristik kesalahan yaitu mahasiswa gagal dalam menentukan dan memilih prosedur pembuktian yang tepat serta kurang lengkap dalam mengaplikasikan rencana yang dipilih. Kesalahan keterampilan proses dengan rata-rata $29,04 \%$, dengan karakteristik kesalahan yaitu mahasiswa salah dalam menentukan alasan tiap pernyataannya. Kesalahan penulisan jawaban dengan rata-rata 23,53\%, dengan karakteristik kesalahan yaitu mahasiswa tidak tepat dalam menyimpulkan hasil akhir pembuktian. Diperoleh beberapa penyebab mahasiswa melakukan kesalahan dalam menyeselaikan soal pembuktian geometri menurut Teori Newman yaitu mahasiswa tidak dapat memilih rencana pembuktian yang sistematis dan tidak dapat menentukan alasan untuk pernyataan yang digunakan. Terdapat beberapa solusi untuk meminimalisir kesalahan dalam mengerjakan soal pembuktian geometri diantaranya hendaknya mahasiswa berinisiatif untuk sering berlatih dengan berbagai jenis soal pembuktian non-rutin agar terus mengasah kemampuan pembuktian matematis. Hasil penelitian ini hendaknya dijadikan bahan evaluasi untuk pihak terkait agar capaian pembelajaran mata kuliah geometri terlaksana dengan baik.

\section{DAFTAR PUSTAKA}

Alhassora, N. S. A., Abu, M. S., \& Abdullah, H. (2017). Newman Error Analysis on Evaluating and Creating Thinking Skills. Man In India, 19(97), 413-427.

Amir, M. F. (2015). Analisis Kesalahan Mahasiswa PGSD Universitas Muhammadiyah Sidoarjo dalam Menyelesaikan Soal Pertidaksamaan Linier. Jurnal Edukasi, 1(2), 131-145.

Budiarto, M. T., \& Artiono, R. (2019). Geometri Dan Permasalahan Dalam Pembelajarannya (Suatu Penelitian Meta Analisis). JUMADIKA : Jurnal Magister Pendidikan Matematika, 1(1), 9-18. https://doi.org/10.30598/jumadikavol1iss1 year2019page9-18

Capraro, R. M., \& Capraro, M. M. (2006). Are you really going to read us a story? Learning geometry through children's mathematics literature. Reading Psychology, 27(1), 21-36. https://doi.org/10.1080/02702710500468716

Csáky, A., Szabová, E., \& Naštická, Z. (2015). Analysis of Errors in Student Solutions of Context-Based Mathematical Tasks. Acta Mathematica Nitriensia, 1(1), 68-75. https://doi.org/10.17846/amn.2015.1.1.68-75

Fitriyah, N. N. (2016). Analisis Kemampuan Pemecahan Masalah Dan Kesalahan Siswa Kelas VII Dalam Menyelesaikan Soal Cerita Pada Materi Segi Empat Melalui PBL. 1-157.

Hanafi, M. A. (2018). Deskripsi Kesulitan Belajar Geometri Mahasiswa Program Studi Pendidikan Matematika Fakultas Keguruan dan Ilmu Pendidikan Universitas Cokroaminoto Palopo. Prosiding Seminar Nasional, 03(1), 273-283.

Hermanto, Kodirun, \& Anggo, M. (2016). Analisis Kemampuan Pembuktian Matematis Siswa SMA Terhadap Matriks Ditinjau Dari Pengetahuuan Awal Matematika. Jurnal Pembelajaran Berpikir 
1407 Analisis Jawaban Mahasiswa dalam Menyelesaikan Soal Pembuktian Geometri Berdasarkan Teori Newman - Syifa Afidah Nurul Arifin

DOI: https://doi.org/10.31004/edukatif.v3i4.564

Matematika, 1(6), 11-18.

Imswatama, A., \& Muhassanah, N. (2016). Analisis Kesalahan Mahasiswa Dalam Menyelesaikan Soal Geometri Analitik Bidang Materi Garis Dan Lingkaran. Suska Journal of Mathematics Education, 2(1), 1. https://doi.org/10.24014/sjme.v2i1.1368

Inayah, W. N. (2019). Analisis kesalahan dalam menyelesaikan soal cerita matematika berdasarkan Newman's Error Analysis (NEA) ditinjau dari kemampuan komunikasi matematis. UIN Sunan Gunung Djati Bandung.

Iskandar, R. S. F., \& Andriyani, R. (2016). Analisis Kesalahan Pembuktian Matematis Mahasiswa pada Matakuliah Analisis Real. Proseding Seminar Nasional Pendidikan Matematika Dengan Tema "Pengembangan 4C's Dalam Pembelajaran Matematika: Sebuah Tantangan Dalam Pengembangan Kurikulum Matematika", 962 - 967.

Jana, P. (2018). Analisis Kesalahan Mahasiswa Dalam Menyelesaikan Soal Matematika Pada Pokok Bahasan Vektor. Jurnal Mercumatika: Jurnal Penelitian Matematika Dan Pendidikan Matematika, 2(2), 8. https://doi.org/10.26486/jm.v2i2.398

Jihad, A. (2018). Kurikulum dan Pembelajaran Matematika.

Kania, N., \& Arifin, Z. (2019). Analisis Kesulitan Calon Guru Sekolah Dasar Dalam Menyelesaikan Soal Pemecahan Masalah Matematis Berdasarkan Prosedur Newman. SJME (Supremum Journal of Mathematics Education), 3(1), 57-66. https://doi.org/10.31235/osf.io/brwgs

Lestari, N. A. (2018). Implementasi Pembelajaran Matematika Model PACE Untuk Meningkatkan Kemampuan Pembuktian Matematis Pada Mata Kuliah Aljabar Abstrak Mahasiswa S1 Pendidikan Matematika. Jurna Equation IAIN Bengkulu, 1(1), 81-94.

Maryono, I., Amanda, S., Dewi, L., Syaf, A. H., Matematika, P. P., Tarbiyah, F., Sunan, U. I. N., Bandung, G. D., \& No, J. A. H. N. (2018). Melalui Metode Moore. 4(2), 72-82.

Masfingatin, T., Murtafiah, W., \& Krisdiana, I. (2018). Kemampuan mahasiswa calon guru matematika dalam pemecahan masalah pembuktian teorema geometri. Jurnal Mercumatika: Jurnal Penelitian Matematika Dan Pendidikan Matematika, 2(2), 41-50.

Nurjanatin, I., Sugondo, G., \& Manurung, M. M. H. (2017). Analisis Kesalahan Peserta Didik dalam Menyelesaikan Soal Cerita pada Materi Luas Permukaan Balok di Kelas VIII-F Semester II SMP Negeri 2 Jayapura. Jurnal Ilmiah Matematika Dan Pembelajaranya, 2(1), 22-31. https://ejournal.uncen.ac.id/index.php/JIMP/article/view/252

Nurussafa'at, A. F., Sujadi, I., \& Riyadi. (2016). Soal Cerita Pada Materi Volume Prisma Dengan Fong' S Shcematic Model For Error Analysis Ditinjau Dari Gaya Kognitif Siswa ( Studi Kasus Siswa Kelas VIII Semester II Smp It Ibnu Abbas Klaten Tahun Ajaran 2013 / 2014 ). Jurnal Elektronik Pembelajaran Matematika, 4(2), 174-187.

Pamungkas, M. D., \& Wicaksono, A. B. (2019). Analisis kesalahan mahasiswa dalam menyelesaikan soal geometri bidang berdasarkan teori newman.

Riastuti, N., Mardiyana, M., \& Pramudya, I. (2017). Students' Errors in Geometry Viewed from Spatial Intelligence. Journal of Physics: Conference Series, 895(1). https://doi.org/10.1088/1742-6596/895/1/012029

Riccomini, P. J. (2016). How To Use Math Error Analysis To Improve Instruction. 1-24. http://files.ernweb.com/erroranalysis.pdf

Rindyana, B. S. B., \& Chandra, T. D. (2013). Analisis Kesalahan Siswa dalam Menyelesaikan Soal Cerita Matematika Materi Sistem Persamaan Linear Dua Variabel Berdasarkan Analisis Newman. Matematika, 4(1), 3-9.

Rosita, I., \& Abadi, A. P. (2019). Kemampuan pemecahan masalah matematis berdasarkan langkah-langkah 
1408 Analisis Jawaban Mahasiswa dalam Menyelesaikan Soal Pembuktian Geometri Berdasarkan Teori Newman - Syifa Afidah Nurul Arifin

DOI: https://doi.org/10.31004/edukatif.v3i4.564

polya. Prosiding Sesiomadika,

Safitri, D. (2017). Identifikasi Kesalahan Siswa dalam Menyelesaikan Soal Matematika Berdasarkan Metode Analisis Kesalahan Newman. Jurnal Dewantara, III, 47-59.

http://www.ejournal.iqro-metro.co.id/index.php

Singh, P., Rahman, A. A., \& Hoon, T. S. (2010). The Newman procedure for analyzing Primary Four pupils errors on written mathematical tasks: A Malaysian perspective. Procedia - Social and Behavioral Sciences, 8, 264-271. https://doi.org/10.1016/j.sbspro.2010.12.036

Sulistyorini, Y. (2017). Analisis Kesalahan Dan Scaffolding Dalam Penyelesaian Persamaan Diferensial. KALAMATIKA Jurnal Pendidikan Matematika, 2(1), 91. https://doi.org/10.22236/kalamatika.vol2no1.2017pp91-104

Sumule, U., Amin, S. M., \& Fuad, Y. (2018). Error Analysis of Indonesian Junior High School Student in Solving Space and Shape Content PISA Problem Using Newman Procedure. Journal of Physics: Conference Series, 947(1). https://doi.org/10.1088/1742-6596/947/1/012053

Sutarto, H. (2018). Geometri, Teknologi, dan Bagaimana Penggunaannya dalam Kaitannya dengan Keterampilan Pembuktian. 1, 902-909.

Suwanti, V., \& Fayeldi, T. (2018). Analisis Kesulitan Mahasiswa Pendidikan Matematika dalam Menyelesaikan Masalah Pembuktian Pernyataan Matematika. Jurnal Tadris Matematika, 1(2), 175184. https://doi.org/10.21274/jtm.2018.1.2.175-184

Syafri, F. S. (2019). Pengaruh kemampuan representasi siswa dalam pemecahan masalah matematika. Jurnal Pendidikan Matematika, 3(May), 49-55.

Utami, A. D. (2016). Tipe Kesalahan Mahasiswa Dalam Menyelesaikan Soal-Soal Geometri Berdasar Newman'S Error Analysis (Nea). JIPM (Jurnal Ilmiah Pendidikan Matematika), 4(2), 85. https://doi.org/10.25273/jipm.v4i2.842

Yazidah, N. I. (2017). Analisis Kesalahan Menyelesaikan Soal Pembuktian Geometri Euclid Ditinjau Dari Gender Pada Mahasiswa Ikip Budi Utomo Malang. KALAMATIKA Jurnal Pendidikan Matematika, 2(1), 71. https://doi.org/10.22236/kalamatika.vol2no1.2017pp71-80

Yustinaningrum, B., \& Lubis, N. A. (2019). Implementasi Conceptual Change Teaching Dalam Mereduksi Miskonsepsi Mahasiswa Materi Induksi. Prosiding Seminar Nasional Matematika Dan Pendidikan Matematika, 2(1), 39-50. http://ejournal.radenintan.ac.id/index.php/pspm/article/view/3766 